\title{
The reshoring of business services: reaction to failure or persistent strategy?
}

\section{Article}

\section{Accepted Version}

Creative Commons: Attribution-Noncommercial-No Derivative Works 4.0

Albertoni, F., Elia, S., Massini, S. and Piscitello, L. (2017) The reshoring of business services: reaction to failure or persistent strategy? Journal of World Business, 52 (3). pp. 417-430. ISSN 1090-9516 doi: https://doi.org/10.1016/j.jwb.2017.01.005 Available at https://centaur.reading.ac.uk/84152/

It is advisable to refer to the publisher's version if you intend to cite from the work. See Guidance on citing.

To link to this article DOI: http://dx.doi.org/10.1016/j.jwb.2017.01.005

Publisher: Elsevier

All outputs in CentAUR are protected by Intellectual Property Rights law, including copyright law. Copyright and IPR is retained by the creators or other copyright holders. Terms and conditions for use of this material are defined in the End User Agreement.

\section{www.reading.ac.uk/centaur}

\section{CentAUR}

Central Archive at the University of Reading

Reading's research outputs online 


\title{
The Reshoring of Business Services: Reaction to Failure or Persistent Strategy?
}

\begin{abstract}
This paper investigates whether reshoring of business services is the result of company response to performance shortcomings of the initiative offshored or instead is motivated by persisting with original offshoring strategy (disintegration advantages, accessing new markets and costsaving), regardless of offshoring performance. Our empirical analysis, based on data from the Offshoring Research Network, shows that both arguments hold. Moreover, when offshoring had been motivated by accessing to new markets and its performance is unsatisfactory, companies are likely to relocate. However, unsatisfactory performance of activities offshored for efficiency reasons or search of talent, do not necessarily lead companies to relocate elsewhere.
\end{abstract}

Keywords: Reshoring, Relocation, Back-shoring, Offshoring Strategy, Offshoring Failure, Business Services 


\section{Introduction}

For several decades, firms in developed countries have strategically offshored ${ }^{1}$ manufacturing and production activities to emerging economies mostly to exploit cost advantages, while locating value-adding, knowledge-intensive activities in advanced countries to benefit from knowledge pool (Contractor, Kumar, Kundu, \& Pedersen, 2010; Doh, Bunyaratavej, \& Hahn, 2009). Over time, production activities have become increasingly technology intensive, resulting in the evolution of firms' specialization in emerging economies towards more knowledge-intensive production systems. The improvement of technical capabilities and the advances in ICT have also facilitated the relocation of high value added activities (such as $\mathrm{R} \& \mathrm{D}$, engineering services and product development) to emerging economies (Bunyaratavej, Hahn, \& Doh, 2008; Dossani \& Kenney, 2006; Lewin, Massini, \& Peeters, 2009). After decades of offshoring of both production and services (the latter still a growing phenomenon), some companies have started to relocate their offshore activities either back to home countries or to other offshore locations.

The phenomenon of relocating offshored business services has been labelled with several different terminologies (e.g., reshoring, on-shoring, in-shoring, back re-shoring). In this paper, we adopt the term "reshoring" to indicate the voluntary (i.e. not forced by host country governments) partial or total relocation of business initiatives previously offshored, whether to another location or back home ${ }^{2}$. In particular, we refer to the relocation of business processes and activities of companies operating in manufacturing and service industries. The relevance of the phenomenon has been acknowledged by the economic press (The Economist, 2013), consultancy companies (Sirkin, Zinser, Hohner, \& Rose, 2012), transnational institutions (UNCTAD, 2013) and policy makers. The U.S. Administration, for instance, is challenging traditional free-trade cornerstones to bring back home some production activities (Tate, 2014), and, recently, the European Union is considering (or designing) policies to support the re-

\footnotetext{
${ }^{1}$ In this paper, we refer to offshoring as the relocation of firms' activities abroad, either in-house (i.e. offshore captive) or through an external supplier (i.e. offshore outsourcing). While outsourcing is "the subcontracting or contracting-out of activities to [...] organizations that had previously been performed within the firm" (Bunyaratavej, Doh, Hahn Lewin, Massini, \&, 2011, p. 71), offshoring is "the transnational relocation or dispersion of service related activities that had previously been performed in the home country" (Doh, Bunyaratavej, \& Hahn, 2009, p. 926), regardless of the mode of entry.

2 The term "reshoring" is used here to indicate a generic change of location with respect to a previous offshore country. This includes further offshoring (i.e. the relocation to another offshore location) and back-reshoring (i.e. relocation to the home country), which are two different specifications of the generic decision of changing location. However, we reckon that the drivers underlying these two different relocation choices are likely to be similar (e.g. performance shortcomings might trigger the decision to either find a new and more profitable location or go back home).
} 
industrialization (EPRS, 2014). For example, The German government has recently launched the "Industrie 4.0" program, making $€ 200$ million available to boost the manufacturing activity in the country, which embraces also the attraction of economic activity from abroad (including further-reshoring and back-shoring) (Stentoft, Olhager, Heikkilä, \& Thoms, 2016). Although the debate has mostly regarded manufacturing activities, some companies are beginning to bring service jobs back home; for instance, General Electric and General Motors have decided to reshore IT services (The Economist, 2013a).

Despite the rising interest by the mass media and in the public opinion towards reshoring, there is relatively limited scholarly research on the reshoring of manufacturing operations (e.g., Arlbjørn \& Mikkelsen, 2014; Ellram, 2013; Ellram, Tate, \& Petersen, 2013; Fratocchi, Ancarani, Barbieri, Di Mauro, Nassimbeni, Sartor, Vignoli, \& Zanoni, 2016; Gylling, Heikkilä, Jussila, \& Saarinen, 2015; Kinkel \& Maloca, 2009; Martinez-Mora \& Merino, 2014; Tate, Ellram, Schoenherr, \& Petersen, 2014; Stentoft, Olhager, Heikkilä, \& Thoms, 2016), and there is almost no research on the reshoring of business services (an exception is Albertoni, Elia, Fratocchi, \& Piscitello, 2015). This may be due to the lack of systematic data available on this phenomenon, and its relatively small scale.

However, this phenomenon is likely to become more pronounced. Market adjustments are weakening imbalances between advanced and emerging economies in terms of the main drivers underlying the offshoring of business services, i.e. the quest of cost savings and the recruiting of qualified personnel (Lewin, Massini, \& Peeters, 2009; Manning, Massini, \& Lewin, 2008). Over time, labour costs are raising in emerging economies and declining in advanced countries where unemployment rates indicate over supply in the labour market (Arlbjorn \& Mikkelsen, 2014; Van Den Bossche, Gupta, Gutierrez, \& Gupta, 2014). These trends suggest that reshoring of business services (as well as of manufacturing activities) is much more than a managerial fad and it represents a raising opportunity, as well as a threat, for managers and policy makers in advanced and emerging economies.

In order to discuss the economic and social implications of this phenomenon, a deeper understanding of the underlying dynamics and more systematic empirical analyses are required. Using original data from the Offshoring Research Network (e.g. Lewin \& Peeters, 2006), this paper aims at shedding more light on reshoring decisions of business services previously offshored. The literature explains reshoring of manufacturing mainly as a consequence of performance shortcomings (Fratocchi, Di Mauro, Barbieri, Nassimbeni \& Zanoni, 2014; Kinkel \& Maloka, 2009; Kinkel, 2012). We argue that reshoring of business services may be due to not achieving the objectives underlying offshoring decisions (i.e., a somewhat unsatisfactory 
performance) and that it can also be related to the desire of persisting with the original offshoring strategy, regardless of the performance of the offshoring operation (e.g. because the host country does not offer opportunity for further improvements, or the company has reached its strategic goal in that country and therefore a new location is considered). Offshoring decisions have been discussed within the framework based on disintegration, localization and externalization advantages (DLE) (Kedia \& Mukherjee, 2009); here we investigate whether and how these factors, in addition to performance shortcomings, can explain reshoring decisions.

The remainder of the paper is organized as follows. The second section illustrates the conceptual framework explaining offshoring and reshoring of business services as driven by DLE factors. The third section provides empirical evidence from the Offshoring Research Network data and presents econometric estimates on determinants of reshoring. Finally, the last section draws some managerial and policy implications, and discusses possible future research avenues.

\section{The reshoring of business services: Failure vs. Coherent offshoring strategy}

Reshoring of business services may be due to a response to performance shortcomings with respect to the original drivers of the offshoring initiatives, which might arise from changes in external conditions or from managerial mistakes. Alternatively reshoring may be due to the company's persistence to capture the offshoring advantages underlying the original offshoring strategy when the external conditions of the host or other locations change or when the company has reached his strategic goal in that specific host country.

The literature has traditionally associated offshoring of business services to three main factors: disintegration, location-specific and externalization (i.e. DLE) advantages (Kedia \& Mukherjee, 2009). Disintegration may allow greater focus on core competencies and greater flexibility. Localization advantages can be related to the main drivers of internationalization: penetration into new markets, desire to obtain some cost savings, access to natural resources, and identification of new strategic assets (Dunning, 1993; 2000). In particular, with regards to the latter driver, the offshoring of high value adding business services is driven by the quest of new technical and engineering talents at the offshore location (Lewin, Massini, \& Peeters, 2009; Manning Massini, \& Lewin, 2008). Regarding externalization advantages, the literature has focussed on the make or buy decisions outside national and firms' boundaries (offshore outsourcing) (Ellram, 2013; Griffith, Harmancioglu, \& Droge, 2009) based on traditional 
transaction cost economics arguments (e.g., Contractor, Kumar, Kundu, \& Pedersen, 2010; Buckley, 2016; Ellram, Tate, \& Billington, 2008).

In the next two sections, we first discuss the DLE factors as motivations for offshoring, and how they could also explain reshoring decisions; we then discuss how reshoring decisions can be triggered by performance assessment too.

\subsection{The DLE framework and reshoring decisions}

\section{Disintegration}

The disintegration of the value chain provides firms with multiple advantages. First, companies can decrease the complexity of managing foreign initiatives while gaining higher organizational flexibility. Additionally, firms can learn more quickly and adapt more rapidly to market and technology changes, thus reducing the costs, and increasing the effectiveness, of transferring knowledge across boundaries (Kotabe, Parente, \& Murray, 2007). Moreover, splitting business functions into smaller modules also reduces the exposure of proprietary knowledge to third parties, thus reducing misappropriation risks (Gooris \& Peeters, 2016). Finally, the disintegration of the value chain enables firms to choose the best location for each single task, by selecting the geographic areas where it is possible to develop innovative capabilities and exploit external agglomeration economies (e.g. selecting an industrial cluster specialized in the delivery of a best-of-breed products or services, see Manning, 2013).

However, a disintegration strategy also requires subsequent reintegration to reinstate the inter-connections along the value chain. While some activities present a high degree of modularity that enables their offshoring, when the inter-connections are strong, they are more difficult to disintegrate and require more effort for their reintegration as well as higher coordination costs, which may affect negatively their net benefits (Griffith, Harmancioglu, \& Droge, 2009; Larsen, Manning, \& Pedersen, 2013). As a consequence, firms are able to fully exploit the benefits arising from the disintegration advantages when the activity is highly modular. Indeed, modular activities can be shifted more easily across locations to take advantage of different knowledge sourcing opportunities and agglomeration economies, without facing high managerial complexity and misappropriation risks. Therefore, we expect that modular activities are more likely to be re-shored, as relocation enables firms to maintain the coherent disintegration strategy underlying the initial offshoring decision.

\section{Localization}


In the DLE framework, localization advantages are related to three main strategies: (i) to penetrate new markets (market-seeking); (ii) to compete on prices, thus constantly increasing efficiency and reducing their costs (efficiency and resource-seeking); (iii) to differentiate the offerings from those of competitors exploiting innovative skills (asset-seeking) (Lewin, Massini, \& Peeters, 2009; Manning, Massini, \& Lewin, 2008).

First, MNEs whose offshoring activities were motivated by the wish to penetrate new markets may well consider reshoring to access new ones, or they might be following their customers to other locations. Second, companies concerned about achieving cost savings are likely to consider reshoring to new locations that are emerging as alternative cost effective destinations (e.g. from emerging to developing countries), but also to consider backshoring to their home countries where coordination costs may be lower and offer advantages in terms of productivity and technology. Emerging economies, such as China and India, see their competitive advantages threatened by other destinations that are more attractive in terms of cost reduction (e.g. developing economies such as some African countries). Third, companies willing to attain new assets might reshore their activities in order to increasingly appropriate knowledge and talent from offshore locations.

\section{Externalization}

Externalization is normally discussed within the Transaction Cost Economics framework (Coase, 1937; Williamson, 1971; 1991). On the one hand, externalisation advantages derive from reduction of costs allowed by economies of scale, scope, specialization and capabilities of service providers. On the other hand, inter-organizational relationships between a firm and external suppliers also entail additional costs such as search costs for potential suppliers, bargaining and negotiation costs, and contract-related costs (contract designing, monitoring and enforcing). Externalisation decisions stem from a positive balance between benefits and costs of outsourcing.

The literature has shown that the decision to offshore-outsource business services is more likely when transaction costs (which depend on asset specificity, market volatility and uncertainty) are low (Ellram, Tate, \& Billington, 2008). Other factors underlying the decision to offshore-outsource business services relate to the achievement of organizational objectives (e.g. to gain a greater focus on core business), improvement focus (e.g. to improve operating performance), financial and cost objectives (e.g. to reduce investments in assets) and revenue objectives (e.g. to achieve aggressive growth objectives by gaining increased market access) (see Ghodswar \& Vaidyanathan, 2008, for an extensive discussion). 
Following these arguments, we claim that the entry choice underlying an offshoring decision (whether as a subsidiary or using a third party provider) may affect a subsequent reshoring decision. Specifically, the low transaction costs underlying the decision to offshoreoutsource a business function (Ellram Tate, \& Billington, 2008) is likely to enable a firm to switch between suppliers located in different countries, i.e. reshoring, as the relationship with an external supplier can be terminated more easily compared to the decision to shut down an activity set up as a wholly owned subsidiary. Additionally, reshoring may also result from the willingness to pursue the achievement of the specific objectives that motivated outsourceoffshoring in the first place.

In sum, we claim that firms may decide to reshore their activities to continue pursuing the objectives underlying the initial offshoring decision, as explained within the DLE framework. This might happen even in the case of satisfactory performance, e.g. when the company has reached or changed its strategic goal or if the external conditions have changed either in the host country or in other locations.

\subsection{Performance assessment and reshoring decisions}

Reshoring is often explained as stemming from negative performance assessments, i.e. when not achieving the intended objectives. Performance shortcomings may arise from changes in the business context or from managerial mistakes. Changes in the business environment include natural disasters, political turmoil or profound economic downturns that deeply affect the performance of the offshoring initiative. Managerial mistakes arise when firms experience substantial hidden and unexpected costs after implementing a strategic decision, e.g. because a diversification strategy requires more coordination than initially expected, or because the knowledge transfer is more costly than expected (Larsen, Manning, \& Pedersen, 2013). We state that firms are more likely to relocate their activities when they do not achieve a satisfactory performance due to either a change of external conditions or managerial mistakes. Specifically we associate the assessment of performance satisfaction to the location drivers of the DLE framework, which can be about (i) market-seeking, (ii) cost-saving/efficiency-seeking or (iii) strategic asset-seeking strategies.

In terms of market-seeking objectives, the failure to penetrate new markets through offshoring will lead to consider reshoring some business activities to other locations in order to reach the expected revenue outcomes. In particular, we expect that MNEs satisfied by their market penetration will keep their activities in the host location in order to fully exploit their investment, while companies unsatisfied about their sales will relocate either in other countries 
or back home. For example, several firms in the automotive industry heavily invested in Brazil in the last 10 years attracted by the growth potential of the region, and several business providers moved their operations in that area as services - due to their inherent characteristics - locate close to the final customer without the substantial costs required by manufacturing activities. However, unfulfilled expectations regarding the growth of the country led several business providers to disinvest from Brazil when their customers were leaving the country due to unprofitable business conditions.

As for the second driver, cost saving or efficiency-seeking, companies dissatisfied by their ability to reduce costs will consider reshoring their activities. This typically happens either because the company did not foresee some offshoring hidden costs, especially in case of outsourcing, or because some locations that had previously been chosen as destination of low value-added and standardized activities may have lost their attractiveness. For instance, business service hubs such as Bangalore and Hyderabad, traditionally selected for low valueadded ICT services, are transforming from low cost to tech cities, due to wage inflation and the development of advanced competences. As a consequence, these locations are no longer competitive in terms of cost for low value-added activities that are typically located in countries with little protection of labour. Additionally, when better social conditions are established, companies tend to reshore their activities also due to cost inflation. To provide another example, Chinese wages, which were very competitive at the turn of the millennium, have raised more than 20 per cent annually in the period 2008-2013 (Shih, 2013). At the same time, during the same period, wages and prices in advanced countries have been turning downward due to the economic crisis and the development of new technologies enabling a reduction of labour intensity (Arlbjorn \& Mikkelsen, 2014, Van Den Bossche, Gupta, Gutierrez, \& Gupta, 2014). Therefore, companies competing on price cannot afford to keep their activities in a certain host location over the long run if the cost advantages are eroded, and reshoring becomes a reasonable response to new threats (e.g. cost inflation) and opportunities (e.g. the emergence of other lowcost locations) in order to maintain a high performance in terms of cost-saving.

As for the third driver, strategic asset-seeking, when competition is based on product differentiation and innovation, accessing human capital and qualified personnel becomes critical. Indeed, talented employees are the repositories of knowledge within a company; knowledge circulates through the people working within the organization and, compared to other assets, employees are relatively more flexible. Therefore, companies tend to offshore in order to access the needed human capital and to transfer the embedded knowledge within the company. In this way, knowledge can easily circulate across locations with little costs for the 
MNC, but extremely valuable potential results. Knowledge circulating across national borders but within the firm's borders constitutes a possible source of competitive advantage for the company. However, if companies fail to find skilled employees in the host location, they will probably need to reshore to locations where it is possible to find human capital with the required skills and specialized knowledge.

To sum up, we expect that firms will be more likely to reshore when the performance of their foreign venture, as related to the original driver underlying the offshoring initiative, is not satisfactory, due to a change in external conditions or managerial mistakes.

\section{Empirical evidence on the reshoring of business services}

The empirical evidence in this paper is based on the dataset developed by the Offshoring Research Network (ORN), which is one of the most comprehensive initiative for studying offshoring of business services by companies of varied size, in a wide range of industries and countries (Elia, Caniato, Luzzini \& Piscitello, 2014; Lewin \& Peeters, 2006; Lewin, Massini, \& Peeters, 2009). ORN initiated in the Centre for International Business Education and Research (CIBER) of Duke University in the United States, with the participation of an international network of researchers and practitioners counting 13 partner universities and business schools belonging to the following countries: Australia, Belgium, Brazil, China, Denmark, Germany, France, Italy, Japan, Korea, the Netherlands, the United Kingdom, and Spain. Each partner collected data on offshoring of business functions administrative services in their own country and shared them with the other members of the network, thus contributing to the ORN database.

The ORN program tracked global sourcing strategies, drivers, geographic dynamics, risks, entry mode, performance and plans across all industries and business functions through a detailed questionnaire about administrative and technical work from abroad. The respondents to the ORN survey are managers of the companies that implemented the offshoring initiatives (and that are planning reshoring). The survey was sent to a top manager (e.g. CEO, CFO, etc.) to listed companies by email with the request to pass it to colleagues with expert information about offshoring initiatives and reshoring plans of his/her company. The ORN database builds on six repeated surveys starting in 2005; the last survey was administered in 2011.

This dataset benefits from including a remarkably high number of home countries, which reflects the geographic areas covered by ORN partners, whose headquarters are mostly located in the European and US areas. The offshoring flows are directed towards advanced, 
emerging and developing countries. The ORN data utilized in this paper consist of self-reported plans to reshore. The original ORN project was designed to study the offshoring phenomenon using an original comprehensive survey, which covered most aspects of the offshoring of business services at the level of the individual implementation. One of the sections of the survey was explicitly devoted to investigate the future plans of each focal offshoring initiative. Specifically, the ORN data utilized in this paper consist of self-reported plans to reshore (in terms of further-offshoring, back-shoring etc.). This is one possible answer to the specific question about future plans in the next three years. This and other questions from the ORN survey are reported in Appendix B.

Therefore, despite some limitations, we find that the ORN dataset is a valuable source to study reshoring. We believe that reshoring plans are a suitable source of information to study post-offshoring strategies, given the lack of data on this phenomenon. The ORN database remains one of the most extensive data source providing information on the (intention of) reshoring and involving business functions (rather than manufacturing activities) as well as including multiple home countries (rather than a single home location). Finally, the ORN data are extremely useful for our study as they enable linking the drivers of offshoring to the (intention of) reshoring, which we consider to be one of the main contributions of our paper.

Additional data on the host markets, namely on macro-economic performance, culture and institutions, have been compiled from three separate datasets: (i) the World Competitiveness Yearbook; (ii) the World Bank, and (iii) Hofstede (2001). The combination of the ORN survey with external databases is useful also to limit the Common Method bias (Chang, van Witteloostuijn \& Eden, 2010).

\subsection{Descriptive statistics}

The entire ORN dataset comprises more than 5,000 observations; due to missing values in the dependent variable, i.e. planning to relocate offshoring initiatives, our descriptive analysis is based on a sample of 1,526 observations. Additionally, due to missing data in some of the explanatory variables, the sample used in the regression analysis comprises of 454 observations $^{3}$. In this section we provide descriptive analyses on reshoring, entry mode (captive or outsourcing), home country and host country, both for the full sample (i.e. 1,526 observations) and for the subsample (i.e. 454 observations) used in the regression models.

\footnotetext{
${ }^{3}$ The variables that are mostly affected by missing values are related with the entry mode, the host location and the firm size.
} 
The main variable on reshoring derives from a specific section in the ORN survey on the plans for a specific offshoring initiative in the next three years. We integrated the following items: "What are the plans for this implementation for the next three years?" "Relocate to another offshore location part or all offshore activities" and "Relocate back to home country part or all offshore activities", due to the relatively small number of observations in each of these two categories.

Table 1 shows relocation plans and entry mode (make vs. buy) strategies for both the full sample and the subsample used in the regression analysis. The regression sample has comparatively a higher proportion of outsourcing initiatives compared to captive (272 vs. 182, $60 \%$ vs. $40 \%$ ), while the full sample is more balanced (613 vs. $576,52 \%$ vs. $48 \%$ ). The percentage of reshoring plans is around $10 \%$ in both the samples, and for both captive and outsourced initiatives, thus suggesting that entry mode strategies do not affect relocation decisions, as confirmed by the non-significance of the Chi-square test.

Table 1 - Reshoring Plans by Entry Mode

$(\%)$

\begin{tabular}{|c|c|c|c|c|c|c|}
\hline & \multicolumn{3}{|c|}{ Regression sample } & \multicolumn{3}{|c|}{ Full sample } \\
\hline & $\begin{array}{l}\text { No planned } \\
\text { relocation }\end{array}$ & Reshoring & Total & $\begin{array}{l}\text { No planned } \\
\text { relocation }\end{array}$ & Reshoring & Total \\
\hline Captive & $\begin{array}{c}163 \\
(89.56)\end{array}$ & $\begin{array}{c}19 \\
(10.44)\end{array}$ & $\begin{array}{c}182 \\
(100.00)\end{array}$ & $\begin{array}{c}522 \\
(90.63)\end{array}$ & $\begin{array}{c}54 \\
(9.37)\end{array}$ & $\begin{array}{c}576 \\
(100.00)\end{array}$ \\
\hline Outsourcing & $\begin{array}{c}244 \\
(89.71)\end{array}$ & $\begin{array}{c}28 \\
(10.29)\end{array}$ & $\begin{array}{c}272 \\
(100.00)\end{array}$ & $\begin{array}{c}548 \\
(89.40)\end{array}$ & $\begin{array}{c}65 \\
(10.60)\end{array}$ & $\begin{array}{c}613 \\
(100.00)\end{array}$ \\
\hline Subtotal & $\begin{array}{c}407 \\
(89.65)\end{array}$ & $\begin{array}{c}47 \\
(10.35)\end{array}$ & $\begin{array}{c}454 \\
(100.00)\end{array}$ & $\begin{array}{c}1,070 \\
(89.99)\end{array}$ & $\begin{array}{c}119 \\
(10.01)\end{array}$ & $\begin{array}{c}1,189 \\
(100.00)\end{array}$ \\
\hline Not available & - & - & - & 299 & 38 & 337 \\
\hline Total & $\begin{array}{c}407 \\
(89.65)\end{array}$ & $\begin{array}{c}47 \\
(10.35)\end{array}$ & $\begin{array}{c}454 \\
(100.00)\end{array}$ & $\begin{array}{c}1,369 \\
(92.83)\end{array}$ & $\begin{array}{c}157 \\
(10.29)\end{array}$ & $\begin{array}{c}1,526 \\
(100.00)\end{array}$ \\
\hline Pearson $\chi 2$ & & & 0.00 & & & 0.50 \\
\hline
\end{tabular}

Table 2 shows reshoring plans by home countries - Europe, US and the Rest of the World $^{4}$. The home locations involved in reshoring plans are widespread among European countries, the United States and few other countries. There are no significant differences between European and US firms regarding the frequencies of plans to reshore business services.

\footnotetext{
${ }^{4}$ The European countries included in the Europe category are: Belgium, Denmark, France, Germany, Ireland, Italy, Luxembourg, the Netherlands, Norway, Scandinavia, Spain, Switzerland and the United Kingdom. The Rest of the World category includes Australia, Canada, India, Japan and the United Arab Emirates.
} 
Table 2 - Reshoring Plans by Home Locations

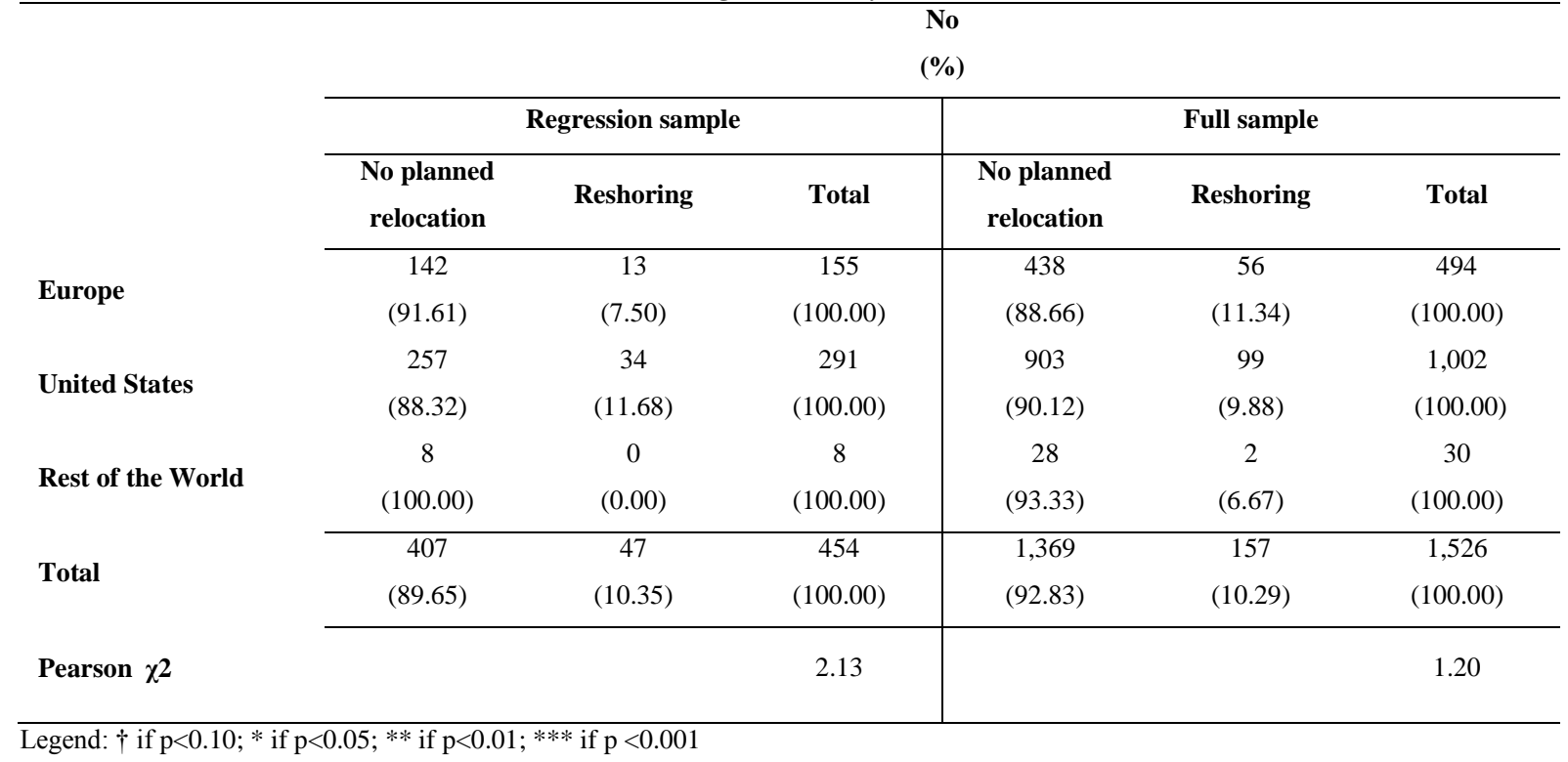

Regarding the host countries, Table 3 shows that reshoring plans are more frequent from Australia and New Zealand (31.3\%) and Western Europe (16.3\%) for the full sample. Thus, the flows of planned reshoring are not necessarily from emerging and developing to advanced countries, but they also depart from advanced countries to be relocated to other locations in the same or in different geographical areas. 


\begin{tabular}{|c|c|c|c|c|c|c|}
\hline & \multicolumn{6}{|c|}{$\begin{array}{l}\text { No } \\
(\%)\end{array}$} \\
\hline & \multicolumn{3}{|c|}{ Regression sample } & \multicolumn{3}{|c|}{ Full sample } \\
\hline & $\begin{array}{c}\text { No planned } \\
\text { relocation }\end{array}$ & Reshoring & Total & $\begin{array}{c}\text { No planned } \\
\text { relocation }\end{array}$ & Reshoring & Total \\
\hline Africa & $\begin{array}{c}3 \\
(100.00)\end{array}$ & $\begin{array}{c}0 \\
(0.00)\end{array}$ & $\begin{array}{c}3 \\
(100.00)\end{array}$ & $\begin{array}{c}24 \\
(85.71)\end{array}$ & $\begin{array}{c}4 \\
(14.29)\end{array}$ & $\begin{array}{c}28 \\
(100.00)\end{array}$ \\
\hline Australia and New Zeeland & $\begin{array}{c}3 \\
(100.00)\end{array}$ & $\begin{array}{c}0 \\
(0.00)\end{array}$ & $\begin{array}{c}3 \\
(100.00)\end{array}$ & $\begin{array}{c}11 \\
(68.75)\end{array}$ & $\begin{array}{c}5 \\
(31.25)\end{array}$ & $\begin{array}{c}16 \\
(100.00)\end{array}$ \\
\hline Asia (except India and China) & $\begin{array}{c}49 \\
(87.50)\end{array}$ & $\begin{array}{c}7 \\
(12.50)\end{array}$ & $\begin{array}{c}56 \\
(100.00)\end{array}$ & $\begin{array}{c}147 \\
(90.18)\end{array}$ & $\begin{array}{c}16 \\
(9.82)\end{array}$ & $\begin{array}{c}163 \\
(100.00)\end{array}$ \\
\hline China and Hong Kong & $\begin{array}{c}39 \\
(92.86)\end{array}$ & $\begin{array}{c}3 \\
(7.14)\end{array}$ & $\begin{array}{c}42 \\
(100.00)\end{array}$ & $\begin{array}{c}126 \\
(94.74)\end{array}$ & $\begin{array}{c}7 \\
(5.26)\end{array}$ & $\begin{array}{c}133 \\
(100.00)\end{array}$ \\
\hline Eastern Europe & $\begin{array}{c}29 \\
(87.88)\end{array}$ & $\begin{array}{c}4 \\
(12.12)\end{array}$ & $\begin{array}{c}33 \\
(100.00)\end{array}$ & $\begin{array}{c}129 \\
(90.21)\end{array}$ & $\begin{array}{c}14 \\
(9.79)\end{array}$ & $\begin{array}{c}143 \\
(100.00)\end{array}$ \\
\hline Western Europe & $\begin{array}{c}39 \\
(88.64)\end{array}$ & $\begin{array}{c}5 \\
(11.36)\end{array}$ & $\begin{array}{c}44 \\
(100.00)\end{array}$ & $\begin{array}{c}149 \\
(83.71)\end{array}$ & $\begin{array}{c}29 \\
(16.29)\end{array}$ & $\begin{array}{c}178 \\
(100.00)\end{array}$ \\
\hline India & $\begin{array}{c}182 \\
(89.66)\end{array}$ & $\begin{array}{c}21 \\
(10.34)\end{array}$ & $\begin{array}{c}203 \\
(100.00)\end{array}$ & $\begin{array}{c}551 \\
(90.33)\end{array}$ & $\begin{array}{c}59 \\
(9.67)\end{array}$ & $\begin{array}{c}610 \\
(100.00)\end{array}$ \\
\hline Latin America & $\begin{array}{c}46 \\
(92.00)\end{array}$ & $\begin{array}{c}4 \\
(8.00)\end{array}$ & $\begin{array}{c}50 \\
(100.00)\end{array}$ & $\begin{array}{c}151 \\
(90.42)\end{array}$ & $\begin{array}{c}16 \\
(9.58)\end{array}$ & $\begin{array}{c}167 \\
(100.00)\end{array}$ \\
\hline Middle East & $\begin{array}{c}0 \\
(0.00)\end{array}$ & $\begin{array}{c}1 \\
(100.00)\end{array}$ & $\begin{array}{c}1 \\
(100.00)\end{array}$ & $\begin{array}{c}13 \\
(92.86)\end{array}$ & $\begin{array}{c}1 \\
(7.14)\end{array}$ & $\begin{array}{c}14 \\
(100.00)\end{array}$ \\
\hline US and Canada & $\begin{array}{c}17 \\
(89.47)\end{array}$ & $\begin{array}{c}2 \\
(10.53)\end{array}$ & $\begin{array}{c}19 \\
(100.00)\end{array}$ & $\begin{array}{c}44 \\
(91.67)\end{array}$ & $\begin{array}{c}4 \\
(8.33)\end{array}$ & $\begin{array}{c}48 \\
(100.00)\end{array}$ \\
\hline Subtotal & $\begin{array}{c}407 \\
(89.65)\end{array}$ & $\begin{array}{c}47 \\
(10.35)\end{array}$ & $\begin{array}{c}454 \\
(100.00)\end{array}$ & $\begin{array}{c}1,345 \\
(89.67)\end{array}$ & $\begin{array}{c}155 \\
(10.33)\end{array}$ & $\begin{array}{c}1,500 \\
(100.00)\end{array}$ \\
\hline Not available & - & - & - & 24 & 2 & 26 \\
\hline Total & $\begin{array}{c}407 \\
(89.65)\end{array}$ & $\begin{array}{c}47 \\
(10.35)\end{array}$ & $\begin{array}{c}454 \\
(100.00)\end{array}$ & $\begin{array}{c}1,369 \\
(92.83)\end{array}$ & $\begin{array}{c}157 \\
(10.29)\end{array}$ & $\begin{array}{c}1,526 \\
(100.00)\end{array}$ \\
\hline Pearson $\chi^{2}$ & & & 10.56 & & & $19.38 *$ \\
\hline
\end{tabular}

Legend: $\dagger$ if $\mathrm{p}<0.10 ; *$ if $\mathrm{p}<0.05 ; * *$ if $\mathrm{p}<0.01 ; * * *$ if $\mathrm{p}<0.001$

The ORN survey is characterized by the presence of very large companies. Companies are divided into three main size categories: small companies (less than 500 full-time equivalent employees - FTE), medium (between 500 and 20,000 FTE), and large (more than 20,000 FTE). Small companies show the highest frequency of plans to reshore their activities in both the full and the regression samples (see Table 4). A possible explanation is that small companies might not have the necessary financial capabilities to successfully sustain business activities located abroad, but at the same time they are more flexible when they need to plan to relocate their activities to another country or back home. 


\begin{tabular}{|c|c|c|c|c|c|c|}
\hline & \multicolumn{6}{|c|}{$\begin{array}{l}\text { No } \\
(\%)\end{array}$} \\
\hline & \multicolumn{3}{|c|}{ Regression sample } & \multicolumn{3}{|c|}{ Full sample } \\
\hline & $\begin{array}{l}\text { No planned } \\
\text { relocation }\end{array}$ & Reshoring & Total & $\begin{array}{l}\text { No planned } \\
\text { relocation }\end{array}$ & Reshoring & Total \\
\hline \multirow{2}{*}{ Small } & 72 & 13 & 85 & 342 & 63 & 405 \\
\hline & $(84.71)$ & $(15.29)$ & $(100.00)$ & (84.44) & $(15.56)$ & $(100.00)$ \\
\hline \multirow{2}{*}{ Midsize } & 168 & 14 & 182 & 432 & 40 & 472 \\
\hline & $(92.31)$ & (7.69) & $(100.00)$ & $(91.53)$ & $(8.47)$ & $(100.00)$ \\
\hline \multirow{2}{*}{ Large } & 167 & 20 & 187 & 587 & 54 & 641 \\
\hline & $(89.30)$ & $(10.70)$ & $(100.00)$ & (91.58) & $(8.42)$ & $(100.00)$ \\
\hline \multirow{2}{*}{ Subtotal } & 407 & 47 & 454 & 1,361 & 157 & 1,518 \\
\hline & $(89.65)$ & $(10.35)$ & $(100.00)$ & (89.66) & (10.34) & $(100.00)$ \\
\hline Not available & - & - & - & 8 & 0 & 8 \\
\hline \multirow{2}{*}{ Total } & 407 & 47 & 454 & 1,369 & 157 & 1,526 \\
\hline & $(89.65)$ & $(10.35)$ & $(100.00)$ & (92.83) & (10.29) & $(100.00)$ \\
\hline Pearson $\chi 2$ & & & 3.65 & & & $16.19 * * *$ \\
\hline
\end{tabular}

\subsection{Regression analysis}

\subsubsection{Dependent variable}

As mentioned above, the dependent variable "Reshoring" captures whether respondents expect to relocate part or all offshore activities to another offshore location or back to the home country. This is operationalized with a dummy variable taking value 1 if the function is planned to be relocated, and 0 otherwise.

\subsubsection{Independent variables}

The independent variables reflect the factors affecting offshoring decisions (DLE factors) and the outcomes of the offshoring initiatives, that is, whether they reached the initial objective or not, as discussed in Section 2.

\section{Disintegration, Localization and Externalization Factors}

We use the variable Business Function Modularity to assess the extent to which each business function is independent from other functions within the value chain, thus providing the firm with the opportunity to exploit disintegration advantages arising from offshoring. The proxy is obtained by the linear additive sum and the reverse coding of two items: the risk of losing synergies across firm activities (measured on a 1 to 5 Likert scale) and the extent to 
which a specific location was chosen to co-locate with existing offshore business processes facilities (also measured on a 1 to 5 Likert scale). The underlying rationale is that, when the risk of losing synergies and the co-location drivers are low, the business function presents a higher degree of independence and modularity.

In order to operationalize localization factors, we include the following offshoring drivers: New Market Penetration, Labour Cost Saving and Availability of Qualified Talents. These three variables capture the drivers of internationalization applied to the context of offshoring of business services and the underlying strategic localization purposes of offshoring initiatives. The question in the survey is the following: "What is the importance of each of the following drivers in considering offshoring this function?"; in the list of the possible drivers, we selected the following items: "Access to new markets for products and services"; "Labour cost savings"; "Access to qualified personnel offshore". All these variables vary on a 1 to 5 Likert scale.

With regard to externalization, we define the dummy variable Outsourcing, which assumes value 1 for Outsourcing ventures and value 0 for the wholly owned, captive ventures. The expectation is that outsourcing initiatives should be more likely to be reshored because they have involved lower fixed costs and higher flexibility, and because the relationship with a service provider can be concluded more easily with respect a captive operation.

\section{Offshoring performance}

We include the outcome of offshoring initiatives in order to understand how postperformance considerations affect reshoring decisions. Following the conventional view that reshoring can be explained by disappointing performance of offshoring initiatives, in the regressions, we include three variables that capture the degree of dissatisfaction with the penetration into new markets (Unsatisfactory Access to New Markets), resource and efficiency seeking strategies (Unsatisfactory Productivity and Efficiency), and asset seeking strategy (Unsatisfactory Access to Qualified Personnel) ${ }^{5}$. We considered the following question in the

\footnotetext{
${ }^{5}$ The literature often adopts profit-related indicators to assess the performance, but the adoption of objective measures in international business is challenged by some issues: (i) companies are reluctant to provide objective data regarding their foreign subsidiaries; (ii) some offshoring ventures (especially in the business service field) are not undertaken in order to obtain financial gains; and (iii) it is not easy to convert data stemming from several countries and companies into a common and consistent unit of measure. Furthermore, the performance of offshoring ventures should be assessed also according to perceptual considerations (Hult, Ketchen, Griffith, Chabowski, Hamman, Dykes, Pollitte \& Cavusgil, 2008; Martin, 2013). Therefore, if non-financial performance needs to be assessed, subjective measures are preferred (Brouthers, 2002). One advantage of subjective indicators is that informed respondents should be able to fully evaluate the success of a certain offshoring venture in a longrun and strategic perspective, unlike financial data that might be affected by short-run biases.
} 
ORN questionnaire: "To what extent do you agree that offshoring has measurably led to the following outcomes?", and, among the list of possible answers, we selected the following ones: "Better access to new markets", "Increased productivity/ efficiency", and "Better access to qualified personnel". All the variables mentioned above vary on a 1 to 5 Likert scale. We reverse coded the items to capture the extent of dissatisfactory performance.

\subsubsection{Control variables}

We consider several control variables. We include one dummy variable (Software and IT functions) to capture Software Development and IT, which represent $37 \%$ of the business functions offshored; one dummy variable (IT sector) to capture the software and IT services industry, which represents $27 \%$ of the offshoring industries ${ }^{6}$; and one categorical variable (Size) to encompass the company size; this is a categorical variable ranging between 0 (small firms) and 2 (large firms).

Age of Offshoring Project is a variable counting the number of years since the offshoring initiative started and indicates the obsolescence of the initiative. The dummy variable Home Country United States captures this country of origin that is the most represented in the sample. The variables Risk of Losing Managerial Control and Risk of Losing Internal Capabilities (both measured on a 1 to 5 Likert scale) capture the extent of uncertainty related to the offshoring of a specific business function, which might trigger reshoring in the later stages of the investment. Market Attractiveness and Political Stability are the result of a factor analysis implemented respectively on the World Competitiveness Yearbook and the World Governance Indicators (source: World Bank) using the average of the data between 2006 and 2011 (the years of the survey). We include these variables to account for the business context of the host countries ${ }^{7}$. Table 5 provides details regarding the construction of these multi-items variables using factor analysis.

When the MNE operates in very diverse business contexts, cultural and geographical distances between home and host countries increase complexity. Offshoring companies are less likely to reshore the activities located in countries that are culturally similar or geographically

\footnotetext{
${ }^{6}$ We performed additional regressions (not included in the paper, but available upon request) which include dummies for all the functions and industries available in the dataset. However, since they are not significant, we follow a parsimonious approach and report the results of the regression including only Software and IT functions and IT sector.

7 These variables are included as control variables because they measure external environment conditions objectively and should not directly affect the strategic decisions. Conversely, respondents' opinions on market conditions directly affect strategic choices and are considered explanatory variables.
} 
close to their headquarters. Therefore, we control for Cultural Distance and for Geographical Distance. The Cultural Distance between the home and host country is computed employing the formula adopted by Kogut and Singh (1988) based on Hofstede (2001) items. We measure Geographical Distance using the reverse coding of the answer to the following question of the ORN survey: "Why was this particular location chosen?", "Geographic proximity" (1 to 5 Likert scale).

We assume that companies with greater offshoring experience are better able to adapt to the host country and are less likely to leave the host location; therefore, we compute the years of experience within the specific host country (variable Country Experience). Finally, the variable Location Portfolio computes the number of locations that the company has already entered at the time of the implementation of the new offshoring initiative. According to the real option view, the MNE is conceived as a "network of activities located in different countries" (Kogut \& Kulatilaka, 1994, p. 123); therefore, MNEs can choose the most appropriate location from their portfolio of countries in order to successfully respond to market conditions or other factors. The option consists in the actual possibility to move activities from one location to another, thus offering operational flexibility to the company. MNEs having a portfolio of activities spread across the world may have greater opportunities to reshore their processes (Belderbos \& Zou, 2009).

The full list of variables included in the regression models is reported in the Appendix A and the survey questions used for this study are shown in Appendix B. 


\section{Table 5 - Exploratory Factor Analysis on Location Variables (Principal Component Analysis with Varimax Rotation)}

\begin{tabular}{|c|c|c|c|c|c|c|}
\hline $\begin{array}{c}\text { First order } \\
\text { construct }\end{array}$ & Items & Source & Description & Scale & Loading & Alpha \\
\hline \multirow{5}{*}{$\begin{array}{c}\text { Market } \\
\text { Attractiveness }\end{array}$} & $\begin{array}{l}\text { Gross Domestic } \\
\text { Product }\end{array}$ & WCY & Gross Domestic Product & $\begin{array}{c}\text { US\$ } \\
\text { billions }\end{array}$ & 0.99 & \multirow{5}{*}{0.79} \\
\hline & $\begin{array}{l}\text { Gross Fixed Capital } \\
\text { Formation }\end{array}$ & WCY & Inward Foreign direct investments & $\begin{array}{c}\text { US\$ } \\
\text { billions }\end{array}$ & 0.95 & \\
\hline & $\begin{array}{l}\text { Direct Investment } \\
\text { Inflows Inward }\end{array}$ & WCY & Direct Investment Inflows Inward & $\begin{array}{c}\text { US\$ } \\
\text { billions }\end{array}$ & 0.87 & \\
\hline & $\begin{array}{l}\text { Government } \\
\text { Consumption } \\
\text { Expenditure } \\
\end{array}$ & WCY & Government Consumption Expenditure & $\begin{array}{c}\text { US\$ } \\
\text { billions }\end{array}$ & 0.97 & \\
\hline & $\begin{array}{l}\text { Household } \\
\text { Consumption } \\
\text { Expenditure } \\
\end{array}$ & WCY & Household Consumption Expenditure & $\begin{array}{c}\text { US\$ } \\
\text { billions }\end{array}$ & 0.97 & \\
\hline \multirow{5}{*}{ Political Stability } & $\begin{array}{l}\text { Political Stability and } \\
\text { Absence of } \\
\text { Violence/Terrorism }\end{array}$ & WGI & $\begin{array}{l}\text { Perception of the likelihood that the } \\
\text { government will be destabilized or } \\
\text { overthrown by unconstitutional or violent } \\
\text { means, including politically-motivated } \\
\text { violence and terrorism. }\end{array}$ & $-2.5 / 2.5$ & 0.88 & \multirow{5}{*}{0.97} \\
\hline & $\begin{array}{l}\text { Government } \\
\text { Effectiveness }\end{array}$ & WGI & $\begin{array}{l}\text { Perception of the quality of public services, } \\
\text { the quality of the civil service and the } \\
\text { degree of its independence from political } \\
\text { pressures, the quality of policy formulation } \\
\text { and implementation, and the credibility of } \\
\text { the government's commitment to such } \\
\text { policies. }\end{array}$ & $-2.5 / 2.5$ & 0.86 & \\
\hline & Regulatory Quality & WGI & $\begin{array}{l}\text { Perception of the ability of the government } \\
\text { to formulate and implement sound policies } \\
\text { and regulations that permit and promote } \\
\text { private sector development. }\end{array}$ & $-2.5 / 2.5$ & 0.90 & \\
\hline & Rule of Law & WGI & $\begin{array}{l}\text { Perceptions of the extent to which agents } \\
\text { have confidence in and abide by the rules } \\
\text { of society, and in particular the quality of } \\
\text { contract enforcement, property rights, the } \\
\text { police, and the courts, as well as the } \\
\text { likelihood of crime and violence. }\end{array}$ & $-2.5 / 2.5$ & 0.89 & \\
\hline & Control of Corruption & WGI & $\begin{array}{l}\text { Perceptions of the extent to which public } \\
\text { power is exercised for private gain, } \\
\text { including both petty and grand forms of } \\
\text { corruption, as well as "capture" of the state } \\
\text { by elites and private interests. }\end{array}$ & $-2.5 / 2.5$ & 0.85 & \\
\hline
\end{tabular}

Note: The factor analysis has been performed on 60 countries. The items have been included in the factor analysis as the average value of the period 2006-2011. Higher values reflect better outcomes for all items. WCY stands for World Competitiveness Yearbook, published by the International Institute for Management Development (IMD) of Lausanne (http://www.imd.org/wcc/), while WGI stands for Worldwide Governance Indicators, published by the World Bank (http://info.worldbank.org/governance/wgi/index.asp). 


\subsubsection{Methodology}

The dependent variable Reshoring is a dummy variable, therefore we estimate the model using a standard logistic regression. Since the distribution of the variable Reshoring presents a high number of zeros and only few ones (of the 454 observations, 47 are reshoring initiatives corresponding to $10.4 \%$ of the sample used for the regression analysis), we use other estimation techniques in order to guarantee robust results. We estimate the model using the Firth logit estimator that fits logistic models by penalized maximum likelihood regression (Heinze \& Schemper, 2002; Firth, 1993). We also use a discrete choice model with complementary log$\log$ specification which is more suitable in the case of rare events, and which estimates the errors using the Huber-White sandwich estimators in order to deal with the risk of not meeting some assumptions (normality, heteroscedasticity, large residuals for some observations) (Long, 1997; Reuer \& Tong, 2005). The results of the three models are overall consistent, with similar coefficients and significances.

\subsubsection{Results}

Table 6 shows the correlation matrix and Table 7 reports the regressions results. Regarding the disintegration factor, our results suggest that offshoring companies are more likely to plan reshoring when the modularity of a business service is high. The variable Business Service Modularity presents a coefficient ranging between 0.19 and 0.22 (with a p-value between 0.02 and 0.06). This suggests that disintegration not only offers an advantage to offshore, as in the DLE framework, but also flexibility that allows companies to consider reshoring their activities.

About localization factors, the variable New Market Penetration is statistically significant across the three models, with a coefficient between 0.48 and 0.52 and a p-value ranging between 0.002 and 0.003 . The variable Labour Cost presents coefficients ranging between 0.34 and 0.38 with p-values ranging between 0.07 and 0.09 , suggesting that efficiencyseeking companies tend to plan reshoring their activities. The variable Availability of Qualified Talent is not statistically significant. These results suggest that the localization factors New Market Penetration and Labour Cost Savings not only explain offshoring choices as in the DLE framework, but they also affect reshoring plans. 
As far as externalization is concerned, our findings show that the dummy variable Outsourcing is not statistically significant; therefore, it appears that the entry mode is not relevant in explaining reshoring intentions, contrary to our prediction that outsourced initiatives are more easily relocated compared to wholly owned operation.

With regards to the performance of the offshoring initiatives, the variable Unsatisfactory Access to New Markets is the only significant one, presenting a coefficient between 0.43 and 0.47 and a p-value between 0.02 and 0.03 . This is consistent with the largely accepted explanation of reshoring, which is due to disappointing outcomes of the offshoring initiatives.

In order to understand the joint effect of unsatisfactory market performance and the associated driver (New Market Penetration) on the probability of reshoring, we analyse the interaction between the two variables and illustrate this effect graphically. Figure 1 illustrates that the relevance of the driver New Market Penetration increases when performance is unsatisfactory, not when the market performance assessment is $\operatorname{good}^{8}$.

On the contrary, the variables Unsatisfactory Productivity and Efficiency and Unsatisfactory Access to Qualified Personnel are not statistically significant, thus suggesting that the intentions to reshore initiatives originally offshored for cost efficiency or searching for talent is more likely to be associated to the companies' desire to persist with their strategies regardless of their performance. In other words, companies reshore their activities when they believe they can find elsewhere the location advantages responding to their original objectives.

Overall, our results suggest that reshoring plans are driven by the degree of interconnections along the value chain, by market-seeking and resource/efficiency-seeking purposes of companies and by performance shortcomings in terms of market penetration.

Some interesting results arise from the analysis of the control variables. The intention to reshore an offshore initiative is less likely in Software and IT functions and in the IT sector (p-value around 0.03 and 0.04), while the Size of the company is not statistically significant. Older initiatives (Age of Offshoring Project) are more likely to be planned to be relocated, probably due to some obsolescence of the investment over time and because of the exhaustion of opportunities in the host location (p-value around 0.02). Initiatives by companies based in the United States are more likely to state they intend to reshore their activities (p-value between

\footnotetext{
${ }^{8}$ To identify initiatives with high and low market performance we considered the mean value of Unsatisfactory Access to New Markets minus and plus one standard deviation, respectively. To show the interaction effect between market driver and performance, we multiplied a dummy identifying the low and high market performance initiatives with the New Market Penetration driver and we plotted the results.
} 
0.02 and 0.04). Reshoring is correlated with Political Stability, probably because stable democracies are also the ones where opportunities are lower. The variables Risk of Losing Managerial Control, Risk of Losing Internal Capabilities, Market Attractiveness, Cultural Distance and Geographical Distance are not statistically significant. The variable Country Experience presents a negative coefficient ranging between -0.23 and -0.26 , with a p-value of 0.11 and 0.14 close to significance, suggesting that greater knowledge of the host country reduces the likelihood of planning to reshore the activity. The experience within the host country probably mitigates the likelihood of reshoring plans because, over time, the offshoring initiative tends to settle in the offshoring location and become more embedded in the local context.

The variable Location Portfolio shows a p-value between 14.4 and 19.4 across the models, which is close to significance. ${ }^{9}$ However, the negative sign is opposite to the expected one, suggesting that companies with a widespread global presence are less likely to plan to reshore their activities. A possible explanation is that companies with a global presence are more likely to rely on longer lasting offshoring initiatives, and can afford to maintain operations that are underperforming, as they can cross-subsidize offshore operations. They do not need to relocate entirely their activities to another location; they could just reduce the presence in markets performing less well and reinvigorate the initiative as the economic situation recovers.

\footnotetext{
${ }^{9}$ Research on discrete dependent variable models suggests that significance levels of up to $20 \%$ can guide inclusion of variables with important interpretative power (Mickey \& Greenland, 1989).
} 


\section{Table 6-Correlation matrix}

\begin{tabular}{|c|c|c|c|c|c|c|c|c|c|c|c|c|c|c|c|c|c|c|c|c|c|c|c|}
\hline & & 1 & 2 & 3 & 4 & 5 & 6 & 7 & 8 & 9 & 10 & 11 & 12 & 13 & 14 & 15 & 16 & 17 & 18 & 19 & 20 & 21 & 22 \\
\hline 1 & Reshoring & 1.00 & & & & & & & & & & & & & & & & & & & & & \\
\hline 2 & Business Function Modularity & 0.02 & 1.00 & & & & & & & & & & & & & & & & & & & & \\
\hline 3 & New Market Penetration Driver & 0.09 & -0.28 & 1.00 & & & & & & & & & & & & & & & & & & & \\
\hline 4 & Labour Cost Driver & 0.04 & 0.08 & -0.27 & 1.00 & & & & & & & & & & & & & & & & & & \\
\hline 5 & Availability of Qualified Talents Driver & 0.04 & -0.05 & 0.08 & 0.20 & 1.00 & & & & & & & & & & & & & & & & & \\
\hline 6 & Outsourcing & 0.00 & 0.39 & -0.21 & 0.21 & 0.05 & 1.00 & & & & & & & & & & & & & & & & \\
\hline 7 & Unsatisfactory Access to New Markets & 0.04 & 0.26 & -0.62 & 0.36 & -0.02 & 0.28 & 1.00 & & & & & & & & & & & & & & & \\
\hline 8 & Unsatisfactory Productivity and Efficiency & -0.06 & 0.04 & 0.02 & -0.10 & -0.27 & -0.03 & 0.09 & 1.00 & & & & & & & & & & & & & & \\
\hline 9 & Unsatisfactory Access to Qualified Personnel & -0.03 & 0.04 & -0.23 & 0.14 & -0.38 & 0.00 & 0.40 & 0.39 & 1.00 & & & & & & & & & & & & & \\
\hline 10 & Software and IT Functions & -0.06 & 0.13 & -0.06 & 0.16 & 0.24 & 0.16 & 0.14 & 0.02 & -0.05 & 1.00 & & & & & & & & & & & & \\
\hline 11 & IT Sector & -0.09 & 0.09 & -0.03 & 0.12 & 0.10 & -0.23 & 0.02 & 0.07 & -0.03 & 0.16 & 1.00 & & & & & & & & & & & \\
\hline 12 & Size & -0.03 & -0.09 & -0.18 & 0.21 & -0.02 & 0.19 & 0.31 & 0.14 & 0.12 & -0.06 & -0.28 & 1.00 & & & & & & & & & & \\
\hline 13 & Age of Offshoring Project & 0.09 & -0.09 & 0.17 & -0.27 & -0.04 & -0.17 & -0.35 & 0.13 & -0.12 & -0.06 & -0.03 & -0.06 & 1.00 & & & & & & & & & \\
\hline 14 & Home Country United States & 0.06 & 0.07 & -0.01 & 0.23 & 0.15 & 0.12 & 0.21 & -0.07 & -0.08 & 0.19 & 0.12 & 0.23 & -0.21 & 1.00 & & & & & & & & \\
\hline 15 & Risk of Losing Managerial Control & 0.09 & -0.28 & -0.06 & 0.02 & 0.04 & 0.03 & 0.02 & -0.04 & 0.11 & -0.05 & -0.11 & 0.00 & -0.05 & -0.15 & 1.00 & & & & & & & \\
\hline 16 & Risk of Losing Internal Capabilities & 0.09 & -0.34 & 0.00 & 0.12 & 0.13 & 0.07 & 0.17 & 0.01 & 0.14 & 0.05 & -0.12 & 0.22 & -0.09 & 0.07 & 0.53 & 1.00 & & & & & & \\
\hline 17 & Market Attractiveness & 0.00 & 0.02 & 0.01 & 0.00 & 0.07 & -0.08 & -0.02 & 0.01 & -0.07 & 0.01 & 0.08 & -0.14 & -0.08 & -0.08 & 0.02 & 0.00 & 1.00 & & & & & \\
\hline 18 & Political Stability & 0.07 & -0.21 & 0.25 & -0.29 & 0.02 & -0.31 & -0.31 & 0.10 & -0.08 & -0.04 & -0.06 & -0.19 & 0.31 & -0.24 & 0.07 & 0.04 & 0.13 & 1.00 & & & & \\
\hline 19 & Cultural Distance & 0.01 & 0.05 & -0.06 & -0.03 & -0.10 & -0.06 & -0.06 & 0.06 & 0.00 & -0.01 & 0.11 & -0.15 & -0.07 & -0.17 & 0.08 & -0.05 & 0.04 & -0.11 & 1.00 & & & \\
\hline 20 & Geographical Distance & 0.05 & 0.29 & -0.22 & 0.03 & -0.22 & 0.23 & 0.19 & 0.10 & 0.07 & 0.00 & -0.06 & -0.06 & -0.03 & 0.00 & -0.06 & -0.17 & 0.00 & -0.34 & -0.03 & 1.00 & & \\
\hline 21 & Country Experience & -0.08 & -0.14 & -0.01 & 0.09 & 0.02 & -0.06 & 0.08 & -0.09 & -0.02 & -0.11 & 0.08 & 0.07 & -0.16 & 0.20 & 0.08 & 0.13 & -0.03 & -0.25 & -0.10 & 0.01 & 1.00 & \\
\hline \multirow[t]{5}{*}{22} & Location Portfolio & -0.09 & -0.13 & 0.23 & -0.34 & -0.17 & -0.18 & -0.44 & 0.16 & -0.14 & -0.12 & -0.16 & -0.02 & 0.03 & -0.23 & 0.09 & -0.03 & -0.01 & 0.27 & 0.19 & -0.15 & -0.08 & 1.00 \\
\hline & Mean & 0.10 & 5.06 & 2.49 & 4.25 & 3.61 & 0.60 & -2.60 & -3.67 & -3.52 & 0.37 & 0.27 & 1.23 & 7.48 & 0.64 & 3.16 & 3.10 & 0.39 & -0.96 & 2.09 & -2.40 & 0.94 & 1.08 \\
\hline & Std. Dev. & 0.31 & 2.09 & 1.43 & 0.99 & 1.32 & 0.49 & 1.39 & 0.94 & 1.06 & 0.48 & 0.45 & 0.74 & 4.93 & 0.48 & 1.16 & 1.17 & 1.05 & 0.97 & 1.08 & 1.43 & 1.44 & 1.99 \\
\hline & Min & 0 & -10 & 1 & 1 & 1 & 0 & -5 & -5 & -5 & 0 & 0 & 0 & 2 & 0 & 1 & 1 & -0.69 & -2.12 & 0.02 & -5 & 0 & 0 \\
\hline & Max & 1 & -2 & 5 & 5 & 5 & 1 & -1 & -1 & -1 & 1 & 1 & 2 & 47 & 1 & 5 & 5 & 6.29 & 1.46 & 5.93 & -1 & 8 & 12 \\
\hline
\end{tabular}


Table 7 -Regression results

\begin{tabular}{|c|c|c|c|}
\hline Reshoring & Logit & Firth logit & Ccomplementary log log \\
\hline \multicolumn{4}{|l|}{ Disintegration } \\
\hline Business Function Modularity & $\begin{array}{l}0.21^{*} \\
(0.11)\end{array}$ & $\begin{array}{l}0.19 \dagger \\
(0.10)\end{array}$ & $\begin{array}{l}0.22 * \\
(0.10)\end{array}$ \\
\hline \multicolumn{4}{|l|}{ Localization } \\
\hline New Market Penetration & $\begin{array}{c}0.52 * * \\
(0.17)\end{array}$ & $\begin{array}{c}0.48 * * \\
(0.16)\end{array}$ & $\begin{array}{c}0.49 * * \\
(0.16)\end{array}$ \\
\hline Labour Cost Saving & $\begin{array}{l}0.38 \dagger \\
(0.21)\end{array}$ & $\begin{array}{l}0.34 \dagger \\
(0.20)\end{array}$ & $\begin{array}{l}0.34 \dagger \\
(0.19)\end{array}$ \\
\hline Availability of Qualified Talent & $\begin{array}{c}0.03 \\
(0.16)\end{array}$ & $\begin{array}{c}0.02 \\
(0.16)\end{array}$ & $\begin{array}{c}0.04 \\
(0.15)\end{array}$ \\
\hline \multicolumn{4}{|l|}{ Externalization } \\
\hline Outsourcing & $\begin{array}{l}-0.43 \\
(0.45)\end{array}$ & $\begin{array}{l}-0.39 \\
(0.42)\end{array}$ & $\begin{array}{l}-0.49 \\
(0.40)\end{array}$ \\
\hline \multicolumn{4}{|l|}{ Performance } \\
\hline Unsatisfactory Access to New Markets & $\begin{array}{l}0.47 * \\
(0.21)\end{array}$ & $\begin{array}{l}0.43^{*} \\
(0.20)\end{array}$ & $\begin{array}{l}0.44^{*} \\
(0.19)\end{array}$ \\
\hline Unsatisfactory Productivity and Efficiency & $\begin{array}{l}-0.11 \\
(0.21)\end{array}$ & $\begin{array}{l}-0.10 \\
(0.20)\end{array}$ & $\begin{array}{l}-0.11 \\
(0.19)\end{array}$ \\
\hline Unsatisfactory Access to Qualified Personnel & $\begin{array}{l}-0.29 \\
(0.23)\end{array}$ & $\begin{array}{l}-0.26 \\
(0.21)\end{array}$ & $\begin{array}{l}-0.25 \\
(0.21)\end{array}$ \\
\hline \multicolumn{4}{|l|}{ Controls } \\
\hline Software and IT Functions & $\begin{array}{l}-0.88^{*} \\
(0.41)\end{array}$ & $\begin{array}{l}-0.80 * \\
(0.39)\end{array}$ & $\begin{array}{c}-0.80^{*} \\
(0.38)\end{array}$ \\
\hline IT Sector & $\begin{array}{l}-1.15^{*} \\
(0.52)\end{array}$ & $\begin{array}{l}-1.01 * \\
(0.49)\end{array}$ & $\begin{array}{l}-1.07 * \\
(0.47)\end{array}$ \\
\hline Size & $\begin{array}{l}-0.27 \\
(0.28)\end{array}$ & $\begin{array}{l}-0.25 \\
(0.27)\end{array}$ & $\begin{array}{l}-0.23 \\
(0.25)\end{array}$ \\
\hline Age of Offshoring Project & $\begin{array}{l}0.08^{*} \\
(0.04)\end{array}$ & $\begin{array}{l}0.08^{*} \\
(0.03)\end{array}$ & $\begin{array}{l}0.07 * \\
(0.03)\end{array}$ \\
\hline Home Country United States & $\begin{array}{l}1.01^{*} \\
(0.46)\end{array}$ & $\begin{array}{l}0.89^{*} \\
(0.44)\end{array}$ & $\begin{array}{l}1.01^{*} \\
(0.43)\end{array}$ \\
\hline Risk of Losing Managerial Control & $\begin{array}{c}0.26 \\
(0.18)\end{array}$ & $\begin{array}{c}0.24 \\
(0.17)\end{array}$ & $\begin{array}{c}0.26 \\
(0.17\end{array}$ \\
\hline Risk of Losing Internal Capabilities & $\begin{array}{c}0.28 \\
(0.19)\end{array}$ & $\begin{array}{c}0.25 \\
(0.18)\end{array}$ & $\begin{array}{l}0.29 \dagger \\
(0.17)\end{array}$ \\
\hline Market Attractiveness & $\begin{array}{l}-0.05 \\
(0.17)\end{array}$ & $\begin{array}{l}-0.02 \\
(0.16)\end{array}$ & $\begin{array}{l}-0.04 \\
(0.16)\end{array}$ \\
\hline Political Stability & $\begin{array}{l}0.37 \dagger \\
(0.22)\end{array}$ & $\begin{array}{l}0.34 \dagger \\
(0.20)\end{array}$ & $\begin{array}{l}0.39 * \\
(0.19)\end{array}$ \\
\hline Cultural Distance & $\begin{array}{l}0.21 * \\
(0.17)\end{array}$ & $\begin{array}{l}0.19 \dagger \\
(0.16)\end{array}$ & $\begin{array}{l}0.22 * \\
(0.15)\end{array}$ \\
\hline Geographical Distance & $\begin{array}{c}0.18 \\
(0.14)\end{array}$ & $\begin{array}{l}-0.16 \\
(0.14)\end{array}$ & $\begin{array}{l}-0.19 \\
(0.13)\end{array}$ \\
\hline Country Experience & $\begin{array}{c}-0.26 \\
(0.16)\end{array}$ & $\begin{array}{l}-0.23 \\
(0.16)\end{array}$ & $\begin{array}{l}-0.24 \\
(0.15)\end{array}$ \\
\hline Location Portfolio & $\begin{array}{c}-0.22 \\
(0.16)\end{array}$ & $\begin{array}{l}-0.19 \\
(0.15)\end{array}$ & $\begin{array}{l}-0.21 \\
(0.14)\end{array}$ \\
\hline Constant & $\begin{array}{l}-5.92 \\
(2.21)\end{array}$ & $\begin{array}{l}-5.30 \\
(2.08)\end{array}$ & $\begin{array}{l}-5.59 \\
(2.06)\end{array}$ \\
\hline Number of observations & & 454 & \\
\hline Zero outcomes & & 47 & \\
\hline Nonzero outcomes & & 407 & \\
\hline Wald/LR chi-square & 55.39 & 37.79 & 57.98 \\
\hline Prob > chi-square & 0.0001 & 0.0136 & 0.0000 \\
\hline Pseudo R square & 0.1833 & - & - \\
\hline
\end{tabular}

Legend: $\dagger$ if $\mathrm{p}<0.10$; * if $\mathrm{p}<0.05 ; * *$ if $\mathrm{p}<0.01 ; * * *$ if $\mathrm{p}<0.001$

Standard errors in parenthesis. 
Figure 1 Interaction effect

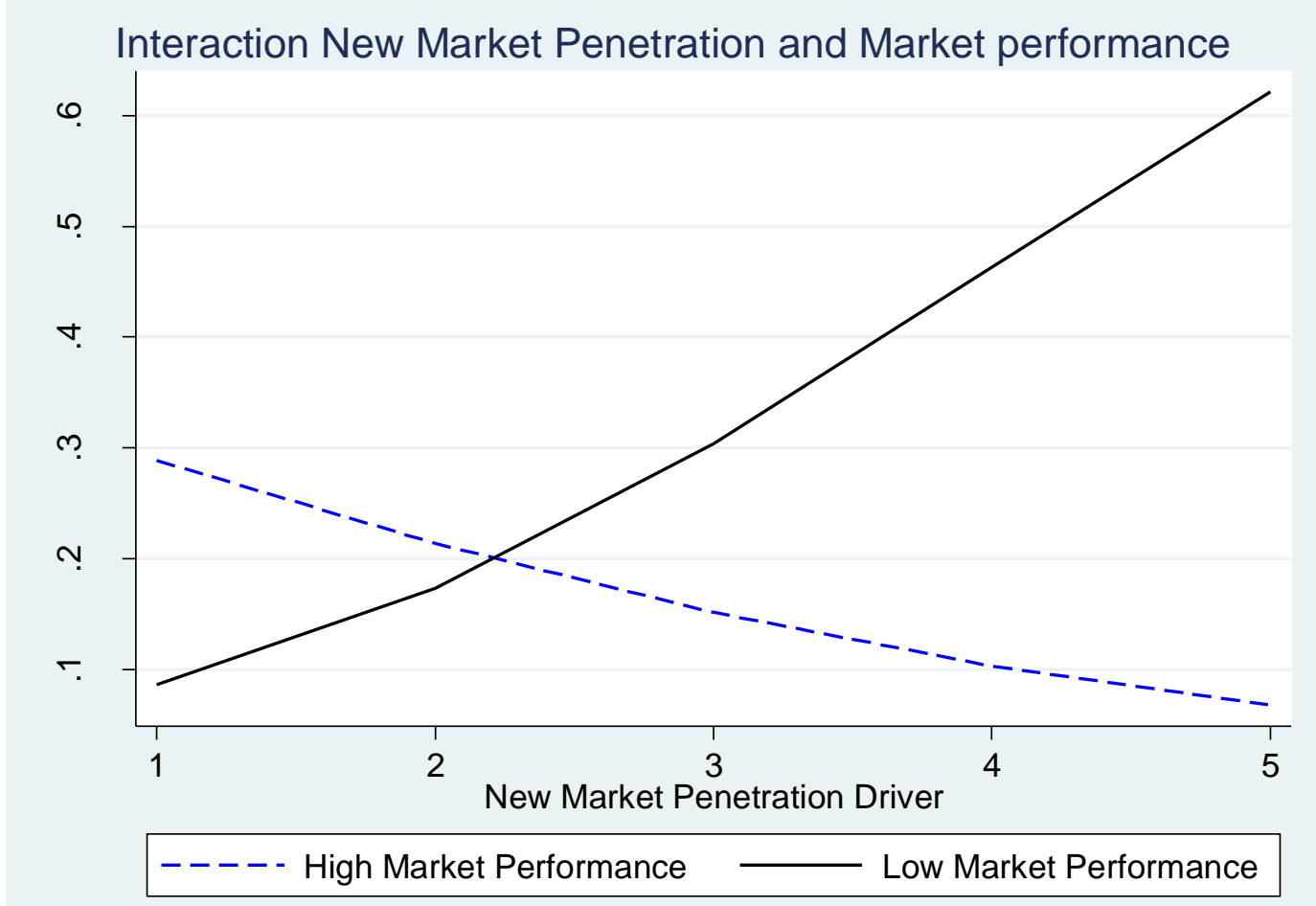

Interaction effect between New Market Penetration and Market Performance (i.e. Unsatisfactory Access to New Markets). 


\section{Discussion and concluding remarks}

This study aims at understanding the reshoring phenomenon. Although several companies are increasingly breaking up and offshoring business processes and activities in order to respond to competitive pressures, some of them have started to consider to relocate their activities, either back home or to other offshore locations. So far, scholars have investigated the reshoring of production activities, and little is known about the reshoring of business services. The main contribution of this paper is to try to fill this gap. Production activities imply high implementation costs hindering their relocation (e.g. the costs of settingup new plants); conversely, business services, which are mainly intangible, and enjoy lower sunk costs and higher flexibility, could be relocated more easily.

In this paper, we explain reshoring plans involving business services as: (i) the pursuit of the original objective that motivated offshoring in the first place, and (ii) the reaction to performance shortcomings. Our empirical results suggest that when the offshoring of service activities had been motivated by cost-saving reasons and to access new markets, and when the latter initiatives perform unsatisfactorily, companies are likely to plan to relocate them. However, unsatisfactory performance of activities that had been offshored for efficiency reasons or in search of talent, do not necessarily lead companies to plan to relocate them elsewhere. These results add to the literature on reshoring that interprets it as mainly driven by failures or unsatisfactory performance. However, we also show that disintegration of the value chain, although being an advantage when companies fragment and offshore selected activities, at the same time facilitates reshoring plans, for example, by offering more flexibility. Overall, our results extend the validity of the DLE framework. Namely, disintegration and location factors may be seen from a double perspective, being at the same time drivers of offshoring and also reshoring plans. These results provide a ground to discuss managerial and policy implications.

\subsection{Managerial Relevance}

Regarding managerial implications, practitioners should carefully consider that offshoring in recent years, and possibly in the years to come, appears to be less convenient compared to how it was few years ago, due to wage and cost inflation in several emerging economies. The correlation between performance shortcomings and reshoring plans suggests that, when the expected outcome is not achieved, some firms start to consider relocating their activities. Managers should be aware of the trade-off between the coordination costs of 
offshoring (while benefitting from labour cost savings at the offshore location) and the less complex management of co-located activities (while bearing higher labour costs at home). Practitioners and business consultants should design their offshoring strategies and implement their operating models

In pursuing long lasting performance from offshoring, managers might need to correct prior sub-optimal decisions, which incur unexpected costs, difficulties or delays. Therefore, the following issues must be analysed in-depth and with particular care: switching costs, make-orbuy opportunities, new location threats and opportunities, and the redesign of the operational model and processes. Management should also plan the reshoring strategy (as an exit strategy) at the offset when planning the offshoring initiative, in order to facilitate its implementation if needed.

The result concerning the disintegration advantage, showing higher probability to plan to reshore modular business services, suggests that managers should take into account interdependencies and co-specialization of business activities when planning their reshoring strategy (and even when planning their offshoring venture). Indeed, if an activity has been offshored to co-locate with other existing business processes facilities, a reshoring strategy might be detrimental, unless applied to the whole group of interconnected activities, which might be moved altogether to another location.

\subsection{Policy implications}

The debate on reshoring has gained interest among policy makers as it is considered to be one of the remedies for unemployment (Gray, Skowronski, Esenduran, \& Rungtusanatham, 2013) and for addressing concerns about innovation capability obsolescence in advanced countries (Pisano \& Shih, 2009, 2012, 2012a). However, the policy makers of these countries should make more efforts not only to incentive the return of previously offshored activities, but also, and above all, to minimize the disinvestments by foreign investors. As our descriptive statistics show that reshoring plans often concern relocating from advanced countries. Hence, European and US industrial policies could try to foster the overall competitiveness of advanced countries and sustain their growth through the implementation of post-investment caring initiatives. For instance, tax incentives, leaner bureaucracy, adoption of advanced manufacturing technologies and further investments in STEM education might enhance the overall attractiveness of these countries for business activities.

At the same time, emerging and developing countries could also consider policy interventions in order to retain production plants and back offices in their countries, given their 
increasingly weakening attractiveness for business sourcing purposes (e.g., due to wage and other cost inflation and eroding comparative advantages). For instance, if past investments in a certain emerging country were motivated by efficiency-seeking purposes, the host country's policy makers should try to improve productivity and control inflation in order to keep their country attractive as an offshoring destination and sustain its competitiveness.

\subsection{Future research}

This paper is based on the ORN survey and provides some evidence concerning the plans to reshore business services. Future research could build on this study in the following ways. First, panel data are recommended to better understand causal relationships among variables. Second, future research should consider collecting data to allow distinguishing between back-shoring and relocation to another offshoring country and test empirically whether the DLE framework and the performance shortcomings explanation holds in both cases. It could also be worth analysing companies' reshoring strategies for high and low/medium value adding activities. Finally, future research could investigate the economic and social impact of reshoring on both developed and emerging economies.

Funding: This work was partially supported by the EUSPRI Forum PhD Circulation Award (Filippo Albertoni) and a Hallsworth Visiting Professorship of The University of Manchester (Lucia Piscitello). 


\section{References}

Albertoni, F., Elia, S., Fratocchi, L. \& Piscitello, L. (2015). Returning from offshore: what do we know? AIB Insights, 15(4): 9-12.

Arlbjørn, J.S. \& Mikkelsen, O.S. (2014). Backshoring manufacturing: notes on an important but under-researched theme. Journal of Purchasing and Supply Management, 20: 6062.

Baaij, M.G., Mom, T.J.M., Van den Bosch, F.A.J. \& Volberda, H.W. (2015). Why do multinational corporations relocate core parts of their corporate headquarters abroad? Long Range Planning, 48: 46-58.

Bailey, D. \& De Propris, L. (2014). Manufacturing re-shoring and its limits: the UK automotive case. Cambridge Journal of Regions, Economy and Society, 7(3): 379-395.

Belderbos, R. \& Zou, J. (2009). Real options and foreign affiliate divestments: a portfolio perspective. Journal of International Business Studies, 40: 600-620.

Blinder, A.S. (2006). Offshoring: the next industrial revolution? Foreign Affairs, 85(2): 113128.

Brouthers, K.D. (2002). Institutional, cultural and transaction cost influences on entry mode choice and performance. Journal of International Business Studies, 33(2): 203-221.

Buckley, P.J. \& Casson, M.C. (1976). The Future of the Multinational Enterprise, London: Homes \& Meier.

Bunyaratavej, K., Hahn, E.D. \& Doh, J.P. (2008). Multinational investment and host country development: location efficiencies for service offshoring. Journal of World Business, 43: 227-242.

Chang, S.J., van Witteloostuijn, A. \& Eden, L. (2010). From the editors: common method variance in international business research. Journal of International Business Studies, 41: 178-184.

Christopher, M \& Holweg, M. (2011). "Supply Chain 2.0”: managing supply chains in the era of turbulence. International Journal of Physical Distribution \& Logistics Management, 41(1): 63-82.

Contractor, F., Kumar, V., Kundu, S. \& Pedersen T. (2010). Reconceptualising the Firm in a World of Outsourcing and Offshoring: The Organizational and Geographical Relocation of High-Value Company Functions. Journal of Management Studies, 47(8): 1417-1433.

Dachs, B. \& Kinkel, S. (2013). Backshoring of production activities in European manufacturing - Evidence from a large-scale survey. Paper presented at the EURopean Operations Management Association Conference. Dublin, Ireland.

Doh, J.P. (2015). Why we need phenomenon-based research in international business. Journal of World Business, 50(4): 609-610.

Doh, J.P., Bunyaratavej, K., \& Hahn E.D. (2009). Separable but Not Equal: The Location Determinants of Discrete Services Offshoring Activities. Journal of International Business Studies, 40(6): 926-943. 
Doh, J., Lewin, A., Massini, S., Hahn, E. \& Bunyaratavej, K. (2011). Conceptual Issues in Services Offshoring Research: A Multidisciplinary Review. Group \& Organization Management, 36(1): 70-102.

Dossani, R., \& Kenney, M. (2006). Reflections upon "Sizing the Emerging Global Labor Market". Academy of Management Perspectives, 20(4), 35-41.

Dunning, J. H. (1993). Multinational Enterprises and the Global Economy. Harlow: AddisonWesley.

Dunning, J. H. (2000). The eclectic paradigm as an envelope for economic and business theories of MNE activity. International Business Review, 9(2), 163-190.

Elia, S., Caniato, F., Luzzini, D. \& Piscitello, L. (2014). Governance choice in global sourcing of services: the impact on service quality and cost saving performance. Global Strategy Journal. 4(3), 181-199.

Ellram, L. M. (2013). Offshoring, reshoring and the manufacturing location decision. Journal of Supply Chain Management, 49(2), 3-5.

Ellram, L.M., Tate, W.L., Billington, C. (2008). Offshore outsourcing of professional services: a transaction cost economics perspective. Journal of Operations Management, 26 : 148-163.

Ellram, L. M., Tate, W. L. \& Petersen, K. J. (2013). Offshoring and reshoring: an update on the manufacturing location decision. Journal of Supply Chain Management, 49(2): 1422.

EPRS (2014). Re-shoring of EU manufacturing. Retrieved from the European Parliament website on April $8^{\text {th }}$ 2015: http://www.europarl.europa.eu/EPRS/140791REV1Reshoring-of-EU-manufacturing-FINAL.pdf

Firth, D. (1993). Bias reduction of maximum likelihood estimates. Biometrika, 80: 27-38.

Fratocchi, L., Ancarani, A., Barbieri, P., Di Mauro, C., Nassimbeni, G., Sartor, M., Vignoli \& Zanoni, A. (2015). Manufacturing back-reshoring as a nonlinear internationalization process. Progress in International Business Research, 10: 365-403.

Fratocchi L, Ancarani A, Barbieri P, Di Mauro C, Nassimbeni G, Sartor M, Vignoli M, \& Zanoni A (2016). Motivations of manufacturing reshoring: an interpretative framework. International Journal of Physical Distribution and Logistics Management, 46: 98-127

Fratocchi, L., Di Mauro, C., Barbieri, P., Nassimbeni, G. \& Zanoni, A. (2014). When manufacturing moves back: concepts and questions. Journal of Purchasing and Supply Management, 20: 54-59.

Ghodswar, B., \& Vaidyanathan, J. (2008). Business process outsourcing: An approach to gain access to world-class capabilities. Business Process Management, 14: 23-38.

Gylling, M., Heikkilä, J., Jussila, K. \& Saarinen, M. (2015). Making decisions on offshore outsourcing and backshoring: a case study in the bicycle industry. International Journal of Production Economics, 162: 92-100.

Gray, J.V., Skowronski, K., Esenduran, G. \& Rungtusanatham, M.J. (2013). The reshoring phenomenon: what supply chain academics ought to know and should do. Journal of Supply Chain Management, 49(2): 27-33. 
Griffith, D. A., Harmancioglu, N. \& Droge, C. (2009). Governance decisions for the offshore outsourcing of new product development in technology intensive markets. Journal of World Business, 44: 217-224.

Gooris, J. \& Peeters, C. (2016). Fragmenting global business processes: a protection for proprietary information. Journal of International Business Studies. Forthcoming.

Guerrieri, P. \& Pietrobelli, C. (2004). Industrial districts' evolution and technological regimes: Italy and Taiwan. Technovation, 24: 899-914.

Harvey, M.G. \& Moeller, M. (2016). A brief commentary on the past, present and future trajectory of the Journal of World Business. Journal of World Business, 51: 6-9.

Heinze, G. \& Schemper, M. (2002). A solution to the problem of separation in logistic regression. Statistics in Medicine, 21: 2409-2419.

Hofstede, G. (2001), Culture's Consequences: Comparing Values, Behaviours, Institutions and Organizations Across Nations, Thousand Oaks CA Sage Publications, second edition.

Hult, T.M., Ketchen, D.J., Griffith, D.A. Chabowski, B.R., Hamman, M.K., Dykes, B.J., Pollitte, W.A. \& Cavusgil S.T. (2008). An Assessment of the Measurement of Performance in International Business Research. Journal of International Business Studies, 39(6): 1064-1080.

Jahns, C., Hartmann, E. \& Bals, L. (2006). Offshoring: dimensions and diffusion of a new business concept. Journal of Purchasing and Supply Management, 12: 218-231.

Kedia, B.L. \& Mukherjee, D. (2009). Understanding offshoring: a research framework based on disintegration, location and externalization advantages. Journal of World Business, 44: 250-261.

Kinkel, S. (2012). Trends in production relocation and back-shoring activities: changing patterns in the course of the global economic crisis. International Journal of Operations and Production Management, 32(6): 696-720.

Kinkel, S. (2014). Future and impact of back shoring - some conclusions from 15 years of research on German practices. Journal of Purchasing \& Supply Management, 20: 6365.

Kinkel, S. \& Maloca, S. (2009). Drivers and antecedents of manufacturing offshoring and backshoring - a German perspective. Journal of Purchasing and Supply Management, 15(3): 154-165.

Kogut, B \& Kulatilaka, N. (1994). Operating flexibility, global manufacturing, and the option value of a multinational network. Management Science, 40(1): 123-139.

Kotabe, M., Parente, R. \& Murray, J. (2007). Antecedents and outcomes of modular production in the Brazilian automobile industry: a grounded theory approach. Journal of International Business Studies, 38(1): 84-106.

Larsen, M. M., Manning, S., \& Pedersen, T. (2013). Uncovering the hidden costs of offshoring: the interplay of complexity, organizational design, and experience. Strategic Management Journal, 34(5): 533-552.

Lewin, A. Y., Massini, S., \& Peeters, C. (2009), Why are companies offshoring innovation? The emerging global race for talent. Journal of International Business Studies, 40(6): 901-925. 
Lewin, A.Y. \& Peeters, C. (2006). Offshoring work: business hype or the onset of fundamental transformation? Long Range Planning, 39: 221-239.

Long, J. S. 1997. Regression models for categorical and limited dependent variables. Thousand Oaks, CA: Sage.

Manning, S., Massini, S., \& Lewin, A. Y. (2008) A dynamic perspective on next-generation offshoring: the global sourcing of science and engineering talent. The Academy of Management Perspectives, 22(3): 35-54.

Manning, S., (2013). New Silicon Valleys or a New Species? Commoditization of Knowledge Work and the Rise of Knowledge Services Clusters. Research Policy, 42: 379-390.

Martin, X. (2013). Solving theoretical and empirical conundrums in international strategy research: Linking foreign entry mode choices and performance. Journal of International Business Studies, 44: 28-41.

Martìnez-Mora, C. \& Merino, F., (2014). Offshoring in the Spanish footwear industry: a return journey? Journal of Purchasing \& Supply Management, 20: 225-237.

Meijboom, B. \& Voss, B., (1997). International manufacturing and location decisions: balancing configuration and co-ordination aspects. International Journal of Operations \& Production Management, 17(8): 790-805.

Mickey, R.M. \& Greenland, S. (1989). The impact of cofounder selection criteria on effect estimation. American Journal of Epidemiology, 129(1): 125-137.

Mudambi, R. (2007). Offshoring: economic geography and the multinational firm. Journal of International Business, 38(1): 206.

Mudambi, R. (2008). Location, control and innovation in knowledge intensive industries. Journal of Economic Geography, 8(5): 699-725.

Pisano, G. P., \& Shih, W. (2009). Restoring American Competitiveness. Harvard Business Review, 87(7/8): 114-125.

Pisano, G. P., \& Shih, W. (2012). Does America really need manufacturing? Harvard Business Review, 90(3): 94-102.

Pisano, G. P., \& Shih, W. (2012a). Producing Prosperity: Why America Needs a Manufacturing Renaissance. Harvard Business Review Press, Boston.

Platts, K.W. \& Song, N. (2010). Overseas sourcing decisions: the total cost of sourcing from China. Supply Chain Management: An International Journal, 15(4): 320-331.

Rangan, S. (1998). Do multinationals operate flexibly? Theory and evidence. Journal of International Business Studies, 29: 217-237.

Reuer, J.J. \& Tong, T. W. Real options in international joint ventures. Journal of Management, 31(3): 403-423.

Shih, W. (2013). The resurgence of manufacturing in America. Inside Supply Management: $30-$ 33.

Sirkin, H., Zinser, M., Hohner, D. \& Rose, J. (2012). "US Manufacturing Nears the Tipping Point: Which Industries? Why, and How Much?", BCG Perspectives, available at: https://www.bcgperspectives.com/content/articles/manufacturing_supply_chain_ma nagement_us_manufacturing_nears_the_tipping_point/ (accessed February $18^{\text {th }}$, 2016).

Stentoft, J., Olhager, J., Heikkilä, J. \& Thoms, L. (2016). Manufacturing backshoring: a systematic literature review. Operations Management Research, 10(3): 1-10. 
Tate, W. L. (2014). Offshoring and re-shoring: US insights and research challenges. Journal of Purchasing \& Supply Management, 20: 66-68.

Tate, W. L., Ellram, L. M., Schoenherr, T. \& Petersen, K. J. (2014). Global competitive conditions driving the manufacturing location decision. Business Horizons, 57(3): 381-390.

The Economist (2013). Offshoring: welcome home. (online), available at: http://www.economist.com/news/leaders/21569739-outsourcing-jobs-farawayplaces-wane-will-not-solve-wests (accessed October $1^{\text {st }}, 2015$ )

The Economist (2013a). The next big thing. (online), available at: http://www.economist.com/news/special-report/21569576-developed-countries-arebeginning-take-back-service-industry-jobs-too-next-big (accessed, May $25^{\text {th }}, 2016$ )

UNCTAD (2013). World Investment Report 2013. Global Value Chains Investment for Development. New York and Geneva: United Nations.

Van den Bossche, P, Gupta, P., Gutierrez, H. \& Gupta, A. (2014). Solving the reshoring dilemma. Supply Chain Management Review: 26-36.

Von Krogh, G., Rossi-Lamastra, C. \& Haefliger, S. (2012). Phenomenon-based research in management and organization science: when is it rigorous and does it matter? Long Range Planning, 45(4): 277-298 


\section{APPENDIX A}

\section{Variables employed in the regression analysis}

\begin{tabular}{|c|c|}
\hline Variables & Operationalization \\
\hline \multicolumn{2}{|l|}{ Dependent } \\
\hline Reshoring & $\begin{array}{l}\text { Dummy = } 1 \text { for considering relocation (further offshoring or back-shoring) of the } \\
\text { offshored activity, } 0 \text { if not considering relocation (ORN Survey). }\end{array}$ \\
\hline \multicolumn{2}{|r|}{ 年 } \\
\hline Business Function Modularity & $\begin{array}{l}1 \text { to } 5 \text { (low to high) linear additive score of "loss of synergies across firm activities" } \\
\text { and "co-locating with existing offshore business processes facilities" for the focal } \\
\text { offshore initiative (ORN Survey). }\end{array}$ \\
\hline New Market Penetration & $\begin{array}{l}1 \text { to } 5 \text { (low to high) of the strategic driver for the focal offshore activity "access to } \\
\text { new markets for products and services" (ORN Survey) }\end{array}$ \\
\hline Labour Cost Saving & $\begin{array}{l}1 \text { to } 5 \text { (low to high) of the strategic driver for the focal offshore activity "labour cost } \\
\text { savings" (ORN Survey) }\end{array}$ \\
\hline Availability of Qualified Talent & $\begin{array}{l}1 \text { to } 5 \text { (low to high) of the strategic driver for the focal offshore activity "access to } \\
\text { qualified personnel offshore" (ORN Survey) }\end{array}$ \\
\hline Outsourcing & Dummy = 1 for outsourcing, 0 if captive (ORN Survey) \\
\hline Unsatisfactory Access to New Markets & $\begin{array}{l}1 \text { to } 5 \text { (low to high) reverse coding of the offshoring outcome "better access to new } \\
\text { markets" (ORN Survey) }\end{array}$ \\
\hline Unsatisfactory Productivity and Efficiency & $\begin{array}{l}1 \text { to } 5 \text { (low to high) reverse coding of the offshoring outcome "increased } \\
\text { productivity/efficiency" (ORN Survey) }\end{array}$ \\
\hline Unsatisfactory Access to Qualified Personnel & $\begin{array}{l}1 \text { to } 5 \text { (low to high) reverse coding of the offshoring outcome "better access to } \\
\text { qualified personnel" (ORN Survey) }\end{array}$ \\
\hline \multicolumn{2}{|r|}{ P } \\
\hline Software and IT Functions & Dummy = 1 for Software Development and IT Infrastructure, 0 for \\
\hline & $\begin{array}{l}\text { Finance/Accounting, Human Resources, Legal Services, Marketing and Sales, } \\
\text { Product Design, Research and Development, Software Development and Supply } \\
\text { Chain and Facilities and other functions (ORN Survey). }\end{array}$ \\
\hline IT Sector & $\begin{array}{l}\text { Dummy = } 1 \text { for Software and IT Services, } 0 \text { for Aerospace and Defence, Arts, } \\
\text { Entertainment and Recreation, Automotive, Construction, Energy, Utilities and } \\
\text { Mining, Financial Service Industry, Government/Public Services, Healthcare, } \\
\text { Manufacturing, Pharmaceuticals and Life Sciences, Professional Services, Retail and } \\
\text { Consumer Goods, Telecommunications, Transportation and Logistics and other } \\
\text { industries (ORN Survey) }\end{array}$ \\
\hline Size & $\begin{array}{l}\text { Categorical variable }=2 \text { for large companies }(>20,000), 1 \text { for midsize companies } \\
(500-20,000 \text { FTE) and } 0 \text { for small companies }(<500 \text { FTE) (ORN Survey) }\end{array}$ \\
\hline Age of Offshoring Project & $\begin{array}{l}\text { Difference between the year of the last survey (2011) and the launch year of the } \\
\text { offshoring initiative (ORN Survey) }\end{array}$ \\
\hline Home Country United States & $\begin{array}{l}\text { Dummy = } 1 \text { for United States as home country, } 0 \text { for other countries from the rest of } \\
\text { the world (ORN Survey) }\end{array}$ \\
\hline Risk of Losing Managerial Control & $\begin{array}{l}\text { Risk perception regarding the loss of managerial control in considering offshoring } \\
\text { the function on a } 1 \text { to } 5 \text { (low to high) Likert scale (ORN survey) }\end{array}$ \\
\hline Risk of Losing Internal Capabilities & $\begin{array}{l}\text { Risk perception regarding the loss of internal capabilities or process knowledge in } \\
\text { considering offshoring the function on a } 1 \text { to } 5 \text { (low to high) Likert scale (ORN } \\
\text { survey) }\end{array}$ \\
\hline Market Attractiveness & $\begin{array}{l}\text { First order construct stemming from an exploratory factor analysis on location } \\
\text { variables; see table } 5 \text { for further details (WGI database) }\end{array}$ \\
\hline Political Stability & $\begin{array}{l}\text { First order construct stemming from an exploratory factor analysis on location } \\
\text { variables; see table } 5 \text { for further details (WGI database) }\end{array}$ \\
\hline Cultural Distance & $\begin{array}{l}\text { Difference between the home and host cultures computed employing the formula } \\
\text { adopted by Kogut and Singh (1988) (Hofstede, 2001) }\end{array}$ \\
\hline Geographical Distance & $\begin{array}{l}1 \text { to } 5 \text { (low to high) reverse coding of the location driver "geographic proximity" } \\
\text { (ORN survey) }\end{array}$ \\
\hline Country Experience & Years of experience in the host country (ORN survey) \\
\hline Location Portfolio & $\begin{array}{l}\text { Global presence of the company, measured in terms of number of host countries } \\
\text { (ORN survey) }\end{array}$ \\
\hline
\end{tabular}




\section{APPENDIX B}

\section{Questions from the ORN Survey Employed in the Analyses}

\begin{tabular}{|c|c|}
\hline Variables & Questions of the survey and values \\
\hline \multicolumn{2}{|l|}{ Dependent } \\
\hline \multirow[t]{3}{*}{ Reshoring } & What are the plans for this implementation for the next three years? \\
\hline & Relocate to another offshore location part or all offshore activities (0-no 1 -yes) \\
\hline & Relocate back to home country part or all offshore activities (0-no 1-yes) \\
\hline \multicolumn{2}{|r|}{$e_{0}$} \\
\hline \multirow[t]{4}{*}{ Business Function Modularity } & $\begin{array}{l}\text { What is the importance of each of the following risks in considering offshoring this } \\
\text { function? }\end{array}$ \\
\hline & Loss of synergy across firm activities (1-'not important' 5-'very important') \\
\hline & Why was this particular location chosen? \\
\hline & $\begin{array}{l}\text { Co-locating with existing offshore business processes facilities (1-'not important' } 5 \text { - } \\
\text { 'very important') }\end{array}$ \\
\hline \multirow[t]{2}{*}{ New Market Penetration } & $\begin{array}{l}\text { What is the importance of each of the following drivers in considering offshoring this } \\
\text { function? }\end{array}$ \\
\hline & $\begin{array}{l}\text { Access to new markets for products and services (1-'not important' 5-'very } \\
\text { important') }\end{array}$ \\
\hline \multirow[t]{2}{*}{ Labour Cost Saving } & $\begin{array}{l}\text { What is the importance of each of the following drivers in considering offshoring this } \\
\text { function? }\end{array}$ \\
\hline & Labour cost savings (1-'not important' 5-'very important') \\
\hline \multirow[t]{2}{*}{ Availability of Qualified Talent } & $\begin{array}{l}\text { What is the importance of each of the following drivers in considering offshoring this } \\
\text { function? }\end{array}$ \\
\hline & Access to qualified personnel offshore (1-'not important' 5-'very important') \\
\hline \multirow[t]{5}{*}{ Outsourcing } & $\begin{array}{l}\text { What is the service delivery model currently used for this offshoring implementation? } \\
\text { Captive (fully owned subsidiary offshore undertakes the activity) }\end{array}$ \\
\hline & Outsourced to an international third party provider offshore (e.g. Infosys, IBM) \\
\hline & Outsourced to a local third party provider at the offshore location \\
\hline & Partnering/teaming arrangement e.g., joint ventures, strategic alliances) \\
\hline & o \\
\hline \multirow[t]{2}{*}{ Unsatisfactory Access to New Markets } & $\begin{array}{l}\text { To what extent do you agree that offshoring has measurably led to the following } \\
\text { outcomes? }\end{array}$ \\
\hline & Better access to new markets (1-'strongly disagree' 5-'strongly agree') \\
\hline \multirow[t]{2}{*}{ Unsatisfactory Productivity and Efficiency } & $\begin{array}{l}\text { To what extent do you agree that offshoring has measurably led to the following } \\
\text { outcomes? }\end{array}$ \\
\hline & Increased productivity/efficiency (1-'strongly disagree' 5-'strongly agree') \\
\hline \multirow[t]{2}{*}{ Unsatisfactory Access to Qualified Personnel } & $\begin{array}{l}\text { To what extent do you agree that offshoring has measurably led to the following } \\
\text { outcomes? }\end{array}$ \\
\hline & Better access to qualified personnel (1-'strongly disagree' 5-'strongly agree') \\
\hline
\end{tabular}




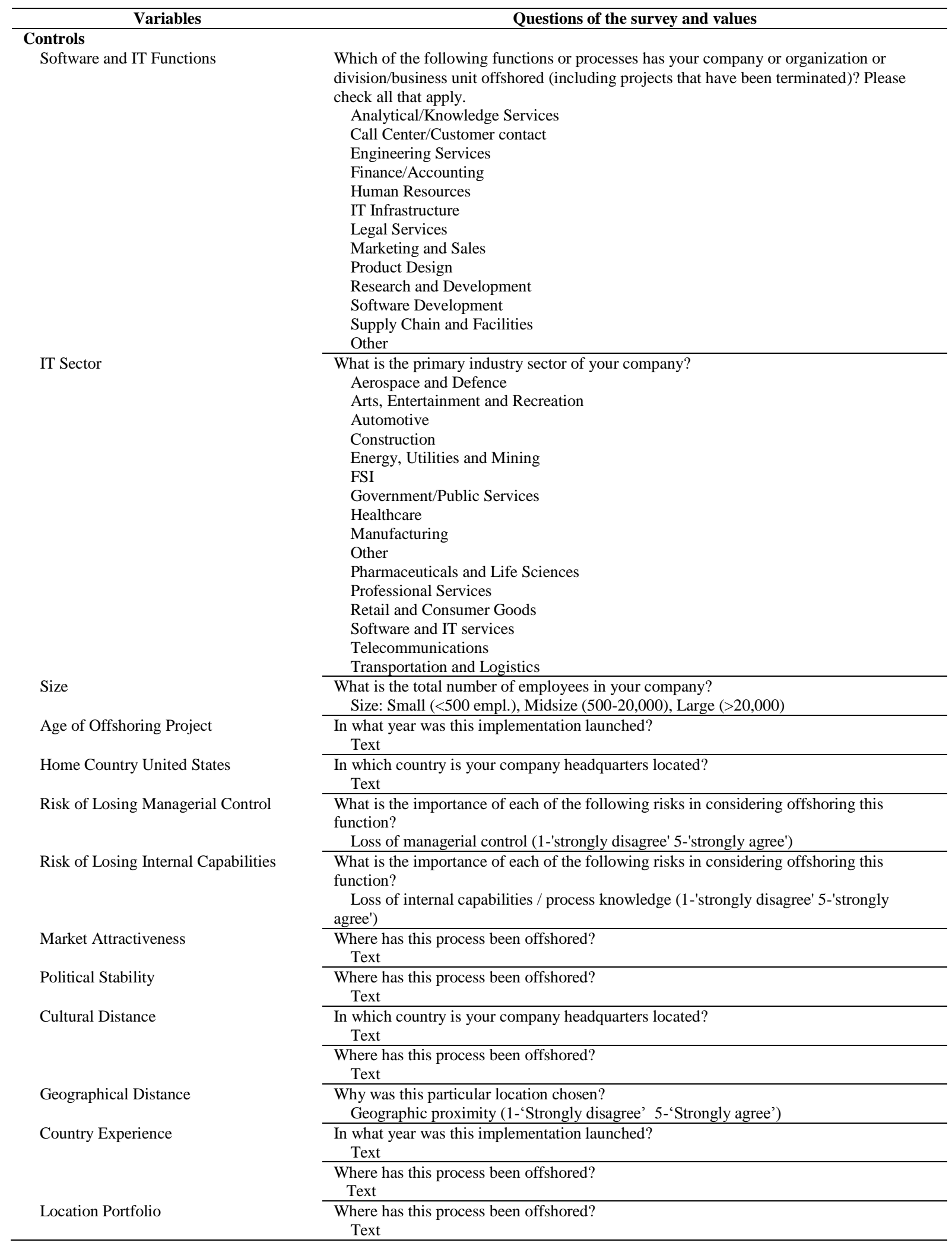

